\title{
Study on the Introduction of Quality International Teaching Resources in Sino-foreign Cooperation in Running Schools under the Background of "Internet + Education"
}

\author{
Xiaobo LIU ${ }^{\mathrm{a},{ }^{*}}$, Dekun ZHOU ${ }^{\mathrm{b}}$ \\ College of Mechanical Engineering, Beihua University, Jilin, 132021, China \\ astone-666@126.com, ${ }^{\mathrm{b}} 735007422 @ q q . c o m,{ }^{*}$ corresponding author
}

Keywords: Internet + education, quality international teaching resources, sino-foreign cooperation in running schools, local engineering colleges

\begin{abstract}
At present, society has entered the era of "Internet +Education". In this context, the survey and ecological analysis of the current situation at home and abroad were introduced. Combining the sino-foreign cooperative education projects of Beihua University, drawing on and introducing foreign high-quality teaching resources and successful experiences, the introduction of foreign high-quality teaching resources in local engineering colleges was studied including problems in the introduction of quality international teaching resources and introduction and integration of international quality teaching resources. It is hoped to explore the mode of cultivation of innovative high-level international talents, and to contribute to the further improvement of the teaching level of higher education in local engineering colleges.
\end{abstract}

\section{Introduction}

The Outline of the National Medium- and Long-Term Education Reform and Development Plan (2010-2020) strengthened the construction and application of quality teaching resources as the top priority for the implementation of education informatization [1, 2]. The "Opinions of the Ministry of Education on Running an Open University" also clearly required that: "we will build a quality curriculum resource that meets diverse learning needs by introducing, learning, utilizing, independent development and other ways" [3]. Therefore, local colleges and universities should fully absorb advanced modern technology and teaching resources at home and abroad, and carry out extensive cooperation so as to enhance the level of application of modern educational technology and the quality of education, improve students' independent learning qualities, and establish talents training system that meet the needs of social development.

When local engineering colleges and universities want to integrate into the world tide of internationalization of higher education, the primary premise is that schools must have clear and international development goals. In accordance with world-class standards, it needs to introduce foreign teaching resources, reconstructs teaching resource systems and establishes world-advanced educational concepts, models and methods, to cultivate high-level talents with international perspectives, international rules, innovation and having ability to participate in international competition [4]. Therefore, how to use the successful experience of advanced national higher education in cultivating innovative talents and how to introduce foreign high-quality undergraduate teaching resources more effectively are of great significance for further improving the quality of undergraduate teaching in local engineering colleges in China. It is also an important means to realize the new round of development goals of China's higher education with quality as its core [5].

In this paper, the survey and ecological analysis of the current situation at home and abroad were introduced. Combining the sino-foreign cooperative education projects of Beihua University, drawing on and introducing foreign high-quality teaching resources and successful experiences, the introduction of foreign high-quality teaching resources in local engineering colleges was studied including problems in the introduction of quality international teaching resources and introduction and integration of international quality teaching resources. It is hoped to explore the mode of cultivation of innovative high-level international talents, and to contribute to the further 
improvement of the teaching level of higher education in local engineering colleges.

\section{Definition of Quality Teaching Resources}

Qualify Teaching Resources includes excellent teaching team, optimized curriculum system, teaching content, good teaching conditions and scientific teaching management[6]. High-quality teaching resources are the core indicators for measuring the level of running a school and its ability to run a school [7]. It has an important decisive and supportive role in the quality of undergraduate specialty talents [7].

\section{Research Status of Introduction of Quality International Teaching Resources in China}

After years of construction, foreign countries already had high-quality teaching resources and had formed a relatively complete library of quality teaching resources, such as the U.S. GEM project, the Australian EdNA project, and the Canadian Edusource project [8]. In addition, various universities have also taken actions one after another. In 2012, the top universities in the United States successively set up e-learning platforms to provide free courses. The rise of curriculum providers such as Coursera, Udacity, and EdX provided more students with the possibility of systematic study. In February 2013, the National University of Singapore cooperated with the American company Coursera to join the large open web course platform [9].

At home, a large number of teaching resources had been built and introduced with the joint efforts of the education department and universities. Based on an analysis of Sino-foreign cooperation in running schools, Business Administration of Ningbo University had explored a way to use grafting to introduce foreign high-quality undergraduate teaching resources and implemented them in this major [10]. The School of Materials Science and Engineering of Nanjing University of Posts and Telecommunications introduced the classic textbooks of American colleges as teaching reference books, excerpting from the video of the class at the Massachusetts Institute of Technology in the United States, combining with Chinese textbooks students used, to form a complete courseware with concise structure, rich content and vivid images [11]. At the same time, a modern curriculum system that combines the actual conditions of our country and our university with international standards had also been established. Chongqing University of Posts and Telecommunications took the overall guiding ideology of "Quality Engineering" and "Undergraduate Teaching Project" of the Ministry of Education as the guide, strengthened the guarantee role of high-quality teaching resources for high-quality personnel training, drew on domestic and foreign excellent teaching materials, innovated teaching management to coordinate and optimize the relationship between the various aspects of the system, strove to cultivate high-quality teaching resources through the construction of instructional reforms, excellent teaching materials and experimental platforms by teaching reforms and research-teaching transformation [7]. Significant achievements had been made in the construction of exemplary undergraduate specialty. Hainan College of Economics [12] and Business and Ningbo City College of Vocational Technology [13] had successfully implemented sino-foreign cooperative education, relying on the introduction of overseas high-quality teaching resources and adopting information methods. They had established long-term and stable exchanges with many overseas educational institutions, which had comprehensively enhanced the school strength and education quality, and laid a foundation for training professional talents with international vision and international standards. Qingdao Technical College introduced teaching resources of leisure management of Netherlands INHOLLAND University of Applied Sciences such as curriculum system, teaching plans and project manuals and sent teachers to study abroad, all of those achieved good results [14].

\section{Problems in Introduction of Quality International Teaching Resources in local engineering colleges}

(1) Insufficient localization of the introduction of curriculum system and teaching content. 
(2) Poor teacher team.

(3) Lack of advanced new media platforms or lack of effective scientific management.

\section{Introduction and Integration of International Quality Teaching Resources}

Introduce and Digest International Quality Curriculum System, Teaching Content and Teaching Methods, and Establish the Integration Mechanism of Domestic and Foreign Teaching Resources. To introduce foreign curriculum systems, teaching contents and teaching methods for the weak links in local engineering colleges and universities. The focus is on professional teaching goals, strengthening students' professional qualities and enhancing students' ability to creatively apply existing knowledge to solve complex problems. At the same time, the external curriculum system and teaching content must be reformed to reflect the characteristics of the socialist university in our country, and in accordance with the relevant regulations of the country, to solve the problem of coordination between nationality and internationalization, and establish a fusion mechanism of foreign and localized teaching resources.

Building an Excellent Team of Teachers for Sustainable Development. Introducing foreign advanced induction training system to train and guide new teachers. Inviting foreign university teachers to teach or train teachers so that teachers can understand and master new teaching models. At the same time, there are plans to send teachers abroad to learn advanced foreign teaching methods. The core is to learn how to train students' ability to innovate and comprehensively use knowledge in the entire teaching process, and how to comprehensively use various teaching methods and teaching facilities to improve the innovative capacity of students. In the whole process of participating in foreign university curriculum teaching, teachers experience advanced teaching ideas, enhance their international vision, and reconstruct their knowledge structure and capability system.

Build a Representative new Media Platform and Increase Scientific Management. The foreign high-quality Blackboard software teaching platform has teaching resource information. In addition, it also has an intelligent course learning help system, which can supervise and guide the student's discussion and learning process, and can provide personalized feedback and intelligent evaluation for student test. Local colleges and universities can learn from the advantages of the Blackboard software teaching platform. With the help of the online courses that are under construction, they can use multimedia information such as hypertext, graphics, images, animations, videos, and sounds to provide more flexible and easier-to-understand teaching formats for all majors, to improve the lack of multimedia resources and audio and video libraries. After students have mastered the technical skills or technical essentials through virtual drills, they will enter the industrial awareness center to conduct practical training. This will enable students to exercise and improve their professional knowledge and skills, achieve a multiplier effect. At the same time, the evaluation system was introduced to fully enhance the teaching effect of resources.

\section{Conclusion}

High-quality teaching resources are the basic guarantee of teaching quality and the basic connotation of characteristic specialty construction. There is still a certain gap between the level of existing personnel training in local engineering universities and foreign advanced universities. The introduction, digestion and absorption of foreign advanced teaching resources is an effective means of accelerating the reform of undergraduate teaching and improving the ability of innovative personnel training in China which needs further improvement through further reform and opening up.

\section{Acknowledgement}

In this paper, the research was sponsored by the Jilin Province Education Science "Thirteen Five" Planning Key Project "Research on the "Internet + Education" Transformation in local engineering colleges based on "double invasive" personnel training" (Project No. ZD17028); The 2016 Teaching Research Project of Beihua University: "Study and Practice of the Teaching Reform of Sino-Foreign 
Cooperation in Local Colleges and Universities - Taking the School of Mechanical Engineering of Beihua University as an Example" (Project No. XJYB2016004); The 2016 Educational Science Project of Beihua University: "Study on the introduction of quality international teaching resources in local engineering colleges under the new background" (Project No. YB201610).

\section{References}

[1] Xiangyang CAI. Exploration on the construction of high-quality teaching resources in higher vocational colleges, Journal of Changsha Social Work College, 2014, 21(3):92-96

[2] Enhao ZHOU, Yuling LI, Ming ZENG. Analysis on the construction of cloud sharing of high quality teaching resources in agricultural universities - take South China Agricultural University as an example, The Chinese Journal of ICT in Education, 2016, (19):44-47

[3] Junjie WANG. Reflections on speeding up the construction of open university in Inner Mongolia, JOURNAL OF INNER MONGOLIA RADIO \& TV UNIVERSITY, 2016, 158(4): 76-78

[4] Bingqing JIANG. Internationalization at home: an ideal option for newly-built local universities, Journal of Hunan University of Humanities, Science and Technology, 2016, 33(2): 99-102

[5] Yi ZHENG, Yumin WANG, Jian CHEN, Xiaoxiang ZHANG. Strengthen the process management of quality teaching resources construction, University Education, 2012, 1(6):14-15

[6] Lan XIONG, Jili CHEN. Problems and countermeasures in the construction of high-quality teaching resources, Software Guide, Educational Technology, 2010, (7):84-86

[7] Xiangdong HU. The practice of building high-quality teaching resources for measurement and control undergraduate specialty, Education Teaching Forum, 2013, (6):211-213

[8] Hua LI. Building and practice of higher vocational colleges'accounting shared Teaching resources, JOURNALOFWUXIINSTITUTEOFTECHNOLOGY, 2010, 9(5):35-37

[9] Kun WANG. Research and Practice of S2C Mixed Teaching Mode in Higher Vocational Colleges, Contemporary Vocational Education, 2016, (8):45-48

[10]Feifan YE, Yun QIU. Grafting Theory and Practice of Teaching Excellence in Higher Education and Teaching Resources, China Higher Education, 2008, (6):53-55

[11]Xingfen LIU, Xiaohui CAI, Lin SHI. Practice of bilingual teaching in material chemistry and exploration of some problems, SCIENCE \& TECHNOLOGY INFORMATION, 2012, (33):24-25

[12] Yanjiang GUO. Hainan College of Economics Building an informatized talent cultivation system to improve employment quality through multiple channels, Education and Vocation, 2014, (31):65-66

[13] Yuqi ZHUANG. Exploration about improvement of Chinese and foreign cooperation English teaching quality, Journal of Mudanjiang University, 2013, 22(3):186-187

[14] Minghua YING. The Exploration and Practice on Carrying Out the Diversified International Cooperation to Cultivate the Tourism Talents, Journal of Qingdao Technical College, 2010, 23(2):

52-54, 62 